\title{
Hvad er opstandelseslegemets karakter ud fra Første Korintherbrev 15?
}

\author{
Stud.theol. BA i teologi og mission fra Fjellhang \\ International University College Denmark \\ Daniel Mikkelsen, Københavns Universitet
}

\begin{abstract}
The article examines the character of the resurrection body in 1 Corinthians 15,36-58 focusing on exegesis and vocabulary. The examination pays special attention to the two most dominating views of the resurrection body in recent scholarly debate, the resurrection of renewed flesh and the resurrection in pneumatic material. The article has three parts. Since both views attend to much of the same terminology, a clarification of their terminology is first given. Next, the exegetical differences between them are lined up against one another. Finally, an exegesis is given which argues that Paul is not talking about a resurrection body composed of ethereal material spirit, but about a body composed of flesh whose state and quality have changed so that it becomes both incorruptible and immortal. This is because the reason for the corruption of the flesh is Adam's fall and sin, not the flesh itself.
\end{abstract}

Keywords: Resurrection - resurrection body - 1 Cor 15 - 1 Cor 15,3658 - pneumatic - flesh - spirit - soulish - psychikos - pneumatikos

\section{Indledning}

Artiklen behandler spørgsmålet om opstandelseslegemets karakter ud fra 1 Kor 15,36-58 i den nyere forskning med vægt på det eksegetisk sproglige. ${ }^{1}$ Før dette kan gennemføres, er det nødvendigt at redegøre for begrebsbrugen, fordi de to mest dominerende fløje i den nyere forskning anvender de samme begreber forskelligt. ${ }^{2}$ Debatten handler ikke som førhen om, hvorvidt opstandelseslegemet er mate-

1. Hvis ikke andet er nævnt, er det min egen oversættelse.

2. Et tredje syn, som ikke er bredt repræsenteret, mener, at er oxymoronisk, Brian Schmisek, "The 'Spiritual Body' as Oxymoron in 1 Corinthians 15:44", BTB 45 (2015), 230-238; Joseph A. Fitzmyer, red., First Corinthians: A New Translation with Introduction and Commentary, The Anchor Yale Bible, v. 32 (New Haven; London: Yale University Press 2008), 596. Synet diskuteres ikke, men artiklen fremsætter en simplere og metodisk mere plausibel forståelse af Paulus' argument, der viser, at Paulus velovervejet forklarer opstandelseslegemets karakter. 
rielt eller immaterielt. ${ }^{3}$ Fokus er snarere på, hvilken materie opstandelseslegemet består af. Det ene syn er kødforståelsen, og det andet er åndsforståelsen (Ware 2014, 816). Herunder vil der blive redegjort for enighed og uenighed mellem synene, hvorefter deres eksegetiske forskelligheder vil blive påpeget. Dette gøres med henblik på at skærpe og overskueliggøre diskussionen i eksegesen af 1 Kor 15,36-58.

\section{Enighed og uenighed mellem synene}

Begge syn er enige om, at Paulus mener, at Jesus er opstået, at opstandelsen er legemlig, at legemet er uforgængeligt, at det er undergået en forvandling, og at det er materielt. ${ }^{4}$

Uenigheden består derfor $\mathrm{i}$, hvad der menes med overstående begreber. Legemligheden er der ikke uenighed om, men synene er uenige om, hvad opstandelseslegemets materie er. Brugen af forgængelighed er ikke forskellig, men betegner forskellige ting i de to syn. Forvandlingen er for begge syn befrielse, men befrielsen er noget forskelligt, fordi de ikke er enige om opstandelseslegemets materie. ${ }^{5}$

Kødforståelsen mener, at opstandelseslegemets materie er kød i en forherliget og udødelig tilstand, dvs. at legemets kvalitet er forskellig før og efter opstandelsen, men ikke dets materie. ${ }^{6}$

3. For en historisk forskningsgennemgang se James P. Ware, "Paul's Understanding of the Resurrection in 1 Corinthians 15:36-54", JBL 133, nr. 4 (2014), 809835 (810-817).

4. N. T. Wright, The Resurrection of the Son of God, Christian Origins and the Question of God 3 (London: SPCK 2003), 312-317; Troels Engberg-Pedersen, Cosmology and self in the Apostle Paul: the material spirit (Oxford; New York: Oxford University Press 2010), 26-38.

5. Se Engberg-Pedersen (2010), 31-33 for det ene syn og Ware (2014), 827-831 for det andet.

6. Ware (2014); Wright (2003); Roy E. Ciampa \& Brian S. Rosner, The first letter to the Corinthians, The Pillar New Testament commentary (Grand Rapids, Michigan: Nottingham, England: W. B. Eerdmans Publishing Co. ; Apollos 2010); Jason Maston, "Anthropological Crisis and Solution in the Hodayot and 1 Corinthians 15", NTS 62, nr. 4 (2016), 533-548; Anthony C. Thiselton, The First Epistle to the Corinthians: a commentary on the Greek text, The new international Greek Testament commentary (Grand Rapids, Michigan: Wm. B. Eerdmans Publishing Co. 2000); G. K. Beale \& Benjamin L. Gladd, Hidden but now revealed: a biblical theology of mystery (Downers Grove, IL: IVP Academic 2014); Gordon D. Fee, The First Epistle to the Corinthians, Revised Edition, The New International Commentary on the New Testament (Grand Rapids, Michigan: Wm. B. Eerdmans Publishing Co. 2014). 
Åndsforståelsen mener, at opstandelseslegemets materie er materiel ånd. Legemets materie er forskellig før og efter opstandelsen. ${ }^{7}$

Derfor er forståelsen af forvandlingen også forskellig, da kødforståelsen forstår forvandlingen som en befrielse fra forgængeligheden i kødet, så kødet bliver uforgængeligt, mens åndsforståelsen forstår forvandlingen som en befrielse fra forgængeligt kød til uforgængeligt pneumatisk stof. ${ }^{8}$

Uenigheden mellem synene er grundlæggende et forskelligt syn på kødet. ${ }^{9}$ Kødforståelsen ser ikke kødet som noget, der grundlæggende er forgængeligt, men snarere som noget, der er blevet underlagt forgængeligheden. Kødets forgængelighed skal derfor ændres til uforgængelighed, før det kan arve Guds rige (Ciampa \& Rosner 2010, 762-764, 817; Fee 2014, 873-874; Wright 2003, 333-338; Maston 2016, 543-544; Beale \& Gladd 2014, 129-135). Åndsforståelsen ser kødet som noget, der er forgængeligt per se, og derfor må materien ændres til en udødelig materie, før det kan arve Guds rige (EngbergPedersen 2010, 19-22, 26-28; Martin 1995, 126-129; Asher 2000, 106-110, 156 note 20; Dunn 2002, 15-16).

\section{Begrebsbrug}

Begreberne anvendes som følgende i artiklen: Fysisk anvendes i begge syn og er derfor overflødigt. Derfor vil kødelig overfor åndelig og forholdet mellem kontinuitet og diskontinuitet af materie blive brugt i stedet. Desuden vil tilstanden før og efter opstandelsen blive vægtlagt og diskussionen vil centrere sig om kvalitativ- overfor materieændring.

7. Engberg-Pedersen (2010); Dale B. Martin, The Corinthian Body (New Haven u.a.: Yale Univ. Press 1995); James D. G. Dunn, "How Are the Dead Raised? With What Body Do They Come?: Reflections on 1 Corinthians 15", SJT 45, nr. 1 (Fall 2002): 4-18; Richard C. Carrier, "The Spiritual body of Christ and the Legend of the Empty Tomb", i The empty tomb: Jesus beyond the grave, red. Robert M. Price \& Jeffery Jay Lowder, 2005 (Amherst, N.Y: Prometheus Books 2005), 105-231; Lars Sandbeck \& Anders Eyvind Nielsen, Kristi opstandelse: sprog og virkelighed (København: Eksistensen 2016); Jeffrey R. Asher, Polarity and change in 1 Corinthians 15: a study of metaphysics, rhetoric, and resurrection, Hermeneutische Untersuchungen zur Theologie 42 (Tübingen: Mohr Siebeck 2000).

8. Se note 5

9. En anden ting, som også skiller synene, er, hvor influereret Paulus er af græsk filosofi. Dette behandles af pladshensyn ikke. Se evt. Wright (2003), 312-317; Engberg-Pedersen (2010), 8-19. 
Eksegetiske forskelle mellem de to mest dominerende syn

Kødforståelsen repræsenteres i fremstillingen af N.T Wright og åndsforståelsen af Troels Engberg-Pedersen. De to syn forstår argumentet således:

Sektion 1: 15,36-41: Kødforståelsen: Så-metaforen i 15,36-38 udtrykker både kontinuitet og diskontinuitet: Der er forskel på frøet og dets plante, men de er stadig organisk forbundne. Analogien peger på, at legemets materie skal ændre tilstand fra forgængelig til uforgængelig efter opstandelsen (Wright 2003, 340-344; Ciampa \& Rosner 2010, 800-804). 15,39-41 er en opremsning, der har baggrunden i Gen 1, som påpeger en diversitet i og forskellighed i Guds skaberværk, og omtaler derfor ikke et stoisk scala natura-hierarki (Wright 2003, 313-314, 340-346). Åndsforståelsen: Så-metaforen illustrerer, hvordan opstandelse kan ske legemligt, og 15,39-41 anvendes til at vise, at der er forskellige legemer - nogle jordiske, andre himmelske med hver deres . Dette stemmer med det stoiske scala naturae-hierarki, hvor det jordiske er af lavere stand/materie og end det himmelske (Engberg-Pedersen 2010, 19-21, 26-28; Martin 1995, 104-108; Asher 2000, 99-106, se også note 34).

Sektion 2: 15,42-44a: Kødforståelsen: 15,42-44a aktualiserer så-metaforen gennem fire paralleller, der klargør forskellen på legemets tilstand før og efter opstandelsen. Legemet sås i forgængelighed, vanære og svaghed som et , og det opstår uforgængeligt, i ære og kraft, som et $\sigma \tilde{\omega} \mu \alpha \pi v \varepsilon v \mu \alpha \tau \iota \kappa o ́ v$. Dette er en kvalitativ (ikke materiel) tilstandsændring fra dødelighed til udødelighed (Wright 2003, 347-49; Ware 2014, 821-825). Andsforståelsen: 15,42-44a udfolder 15,36-41 gennem fire kontraster mellem det nuværende legeme ( $\sigma \tilde{\omega} \mu \alpha \psi v v \chi \imath \kappa o ́ v)$ og opstandelseslegemet ( $\sigma \tilde{\omega} \mu \alpha \pi v \varepsilon v \mu \alpha \tau 1 \kappa o ́ v)$. $\Sigma \tilde{\omega} \mu \alpha \psi v v \chi$ \óv er den forgængelig krop, som sås, mens er kroppen, der opstår i en uforgængelig skikkelse bestående af pneuma. Dette stemmer med det stoiske scala naturae-hierarki, hvor himmellegemerne er de højest placerede og består af pneuma i sin højeste form, og da $\sigma \tilde{\omega} \mu \alpha \pi v \varepsilon v \mu \alpha \tau \imath \kappa o ́ v$ består af samme pneuma som himmellegemerne, er det et himmellegeme (Engberg-Pedersen 2010, 19-22, 26-28; Martin 1995, 126-129; Asher 2000, 106-110, 156 note 20).

Sektion 3: 15,44b-49: Kødforståelsen: I 15,44b-49 citeres Gen 2,7 $(15,45)$ og den jordiske (første) Adam stillet overfor den himmelske (sidste) Adam. Dette skyldes ikke en anvendelse af Filons teori om de to mennesker, hvor mennesket først er åndeligt, der så bindes til kødet og siden må slippe fri af kødet og vende tilbage til en åndelige form. Dette er, fordi menneskets oprindelig form er kødelig og ikke åndelig $(15,46)$. Gud kalder skabelsen - og dermed menneskets 
kødelighed - virkelig god i Gen 1,31. ${ }^{10} 1$ Kor 15,45ff beskriver menneskets tilstand, som blev ødelagt af synden ved Adams fald $(15,22)$. Den sidste Adam, Kristus, er kommet for at føre mennesket ud af dette falds konsekvenser og ind i en ny skabelse, en udødelig kødelig eksistens, i sit himmelske billede (Wright 2003, 353-356). Andsforståelsen: Citatet fra Gen 2,7 introducerer de to Adam'er. Den første Adam er fra citatet, men den sidst Adam bygger på Filons to mennesker. Baggrunden er kun delvis, da kronologien hos Paulus er modsat Filon: først det sjælelige legeme derefter det pneumatiske $(15,46)$. Der er altså forskel på legemet nu og i opstandelsen. Den første Adam er jordisk og forgængelig i sin kødelige krop, som vi bærer nu. Dette er i modsætning til den sidste Adam, som er himmelske med sin udødelige krop af pneumatisk stof, som vi skal bære i opstandelsen (Engberg-Pedersen 2010, 28-31, se også note 77 og 78; Asher 2000, 110-116, se også note 48).

Sektion 4: 15,50-54a: Kødforståelsen: 15,50 er en hebraisk parallelisme, hvor kød og blod sammen med forgængeligheden, der ikke arver Guds rige, modstilles det uforgængelige, som arver Guds rige. Det forgængelige kødelige legeme må derfor forvandles og iklædes uforgængelighed, så det kan arve Guds rige (Wright 2003, 359). Andsforståelsen: 15,50 opsummerer det, som er sagt forud, hvorefter det følgende forklarer, hvordan forvandlingen sker. Den sker, ved at materien ændres gennem en forvandling, som i aristotelisk filosofi kaldes substantiv forandring. ${ }^{11}$ Dvs. at materien (kødet) ændres fuldstændigt til noget andet, men forbliver samtidig "selv-identisk", den samme, $i$ en ny materie (pneuma). ${ }^{12}$

Sektion 5: 15,54b-58: Kødforståelsen: Døden er besejret ved, at legemets materie af kød forvandles fra en forgængelig til en uforgængelig tilstand (Wright 2003, 359-360). Åndsforståelsen: Døden er besejret ved, at legemets materie forvandles fra kød til pneumatisk stof (Engberg-Pedersen 2010, 33-37).

10. Gen 1,26-28 og Gen 2,7 omtaler samme skabelse.

11. Oversættelse af Substantive change (Engberg-Pedersen 2010, 32)

12. Engberg-Pedersen (2010), 31-33; Asher (2000), 156 note 20 (kursiv: EngbergPedersen) 


\section{Eksegese af 1 Korintherbrev 15,36-58 ${ }^{13}$}

\section{5,36-41 Så-metaforen og opremsningen}

Paulus forklarer gennem så-metaforen, at liv kan komme ud af dø-

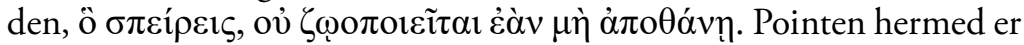
ikke, hvad der botanisk set sker, men der skabes en referenceramme til at forstå, hvorledes opstandelsen fra de døde kan ske. På samme måde som frøet lægges i jorden, og en plante "opstår" derfra, skal den døde krop opstå til nyt liv (Fee 2014, 863-864; Ciampa \& Rosner 2010, 800-801). Metaforens mening er ikke, at døden er en nødvendighed, men at en forvandling finder sted gennem død og opstandelse. ${ }^{14}$ Denne forvandling er fokus i 15,37-38, hvor det adversative $\dot{\alpha} \lambda \lambda \grave{\alpha}$ i 15,37

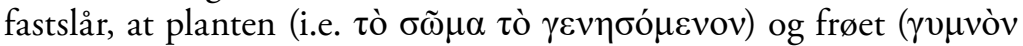
ко́ккоv) ikke er det samme. Selvom forvandlingen af det nøgne frø til en plante er en klar diskontinuitet, er der også organisk kontinuitet mellem planten og frøet. Dette indikeres i 15,38 ved at Gud giver “...

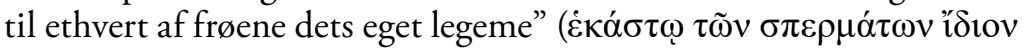
$\sigma \tilde{\omega} \mu \alpha)$, hvilket understreger den organiske kontinuitet mellem frøet og dets plante $(\sigma \tilde{\omega} \mu \alpha)$ (Ciampa \& Rosner 2010, 801-804; Fee 2014, 863-865; Thiselton 2000, 1263-1266. Contra Engberg-Pedersen 2010, 27-28; Schmisek 2015, 232; Martin 1995, 125).

Så-metaforen synes at have ophav i en læsning af Gen 1,11-12 pga. fokusset på Guds skabervilje $(15,38)$ : I Gen 1 skaber Gud træerne og planterne, og i 1 Kor 15,38 gør han frøet til en plante. Dette styrkes af, at opremsningen i 1 Kor 15,39-41 synes at være en omvendt opremsning af skabelsesrækkefølgen i Gen 1,14-28..$^{15}$ Allusionerne til Genesis 1 passer med den eskatologiske nyskabelsesteologi i 1 Kor $15 .^{16}$

13. Debatten om baggrunden for spørgsmålet i 15,35 kan ikke redegøres for her, men det er heller ikke vigtigt for at forstå Paulus' argument, da Paulus i alle tilfælde redegør for opstandelseslegemets karakter. For en redegørelse af den retoriske struktur i 1 Kor 15 se (Asher 2000, 1-99, 119-121); Ben Witherington III, Conflict and community in Corinth: a socio-rhetorical commentary on 1 and 2 Corinthians (Grand Rapids, Mich.: Wm. B. Eerdmans Publishing Co. 1995), 291-312.

14. Thiselton (2000), 1263-1264; Fee (2014), 864; C. K. Barrett, The First Epistle to the Corinthians, Black's New Testament commentary (Peabody, MA: Hendrickson Publishers 1968), 370. Contra Schmisek (2015), 232; Engberg-Pedersen (2010), 27; Ciampa \& Rosner (2010), 801 i forhold til dødens nødvendighed

15. Mennesket (Gen 1,26-28), dyr (Gen 1,24-25), fugle og fisk (Gen 1,20-23) i 1 Kor 15,39 og himmellegemerne (Gen 1,14-19) i 1 Kor 15,40-41 (Ciampa \& Rosner 2010, 805)

16. Ciampa \& Rosner (2010), 803-805; Wright (2003), 340-344; Fee (2014), 867 note 306. Contra Asher (2000), 99-106, se også note 28 og 30). Asher anerkender 15,39-41's ophav i Gen 1, men mener, det er delvist. Dette skyldes ifølge ham, at 


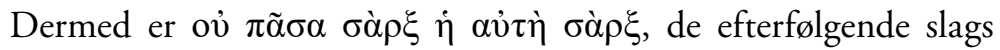
$\sigma \grave{\alpha} \rho \xi$ og himmellegemerne i 15,39-41 eksempler på, hvordan Gud har skabt verden med stor diversitet. ${ }^{17}$ Nok er alle de nævnte slags kød, kød, men de er ikke ens. Det samme gælder himmellegemerne. De er alle himmellegemer, men månen er ikke som solen, og solen og månen er ikke som stjernerne, ja, selv stjernerne er forskellige fra hinanden. ${ }^{18}$ Dette udtrykker ikke en forskel i graden af $\delta$ ò $\xi \alpha$ mellem de jordiske og himmelske legemer, som i den stoiske scala naturae og en lokativ polaritet, men udtrykker snarere forskellig pragt/glans de jordiske og himmelske legemer imellem. ${ }^{19}$ Dette begrundes af følgende tre argumenter:

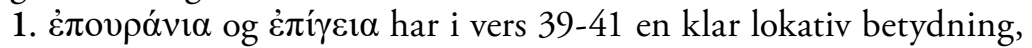
idet der sigtes til, hvor legemerne er placeret i skaberværket - dog ikke deres værdi/status eller en antitetisk polaritet, men blot en neutral anvisning af deres placering i skaberværket. ${ }^{20}$ Dette underbygges af, at et græsk kosmologisk hierarki ikke er fokus i Gen 1, som er baggrunden for opremsningen. ${ }^{21}$

2. Mغ̀े ... $\delta \dot{\varepsilon}$ i 15,40 er ikke en kontrast i størrelsen af pragt/glans

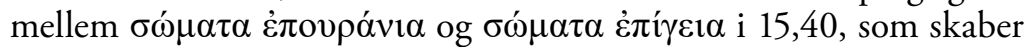
en antitetisk polaritet $\mathrm{i}$ et kosmisk hierarki, men snarere en let kon-

rækkefølgen er omvendt, og at der er syv og ikke kun fire typer dyr/бà $\rho \xi$ i Genesis,

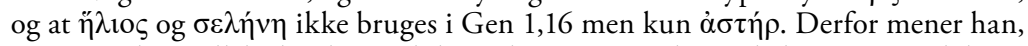
at en græsk parallel til et kosmisk hierarki er mere oplagt - helt præcist en lokativ polaritet mellem de jordiske og himmelske legemer. Dette synes relativt let at tilbagevise, fordi det er muligt at forstå 1 Kor 15,39-41 som en henvisning i overordnede

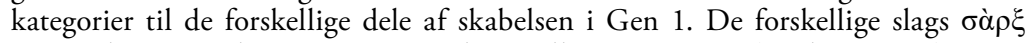
(15:39) henviser til Gen 1,20-28 og himmellegemerne i 15,40 til Gen 1,14-19. At det store lys er solen, og det lille er månen er implicit (Delvist Ciampa \& Rosner 2010, 803-806).

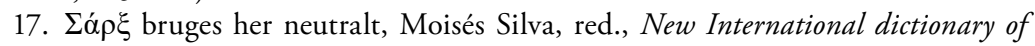
New Testament Theology and Exegesis (Grand Rapids, Michigan: Zondervan ${ }^{2} 2014$ ), 4: 255, NT2(a).

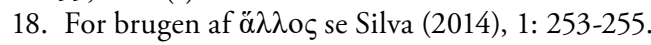

19. Thiselton (2000), 1266-1271; Wright (2003), 313-314, 340-346; Fee (2014), 865-867; Barrett (1968), 371. Contra Engberg-Pedersen 2010, 27-28; Martin 1995, 117-120, 125-126; Jerry L. Sumney, "Post-Mortem Existence and Resurrection of the Body in Paul", HBT 31 (2009): 12-26 (16-17); Asher (2000), 99-106; Carrier (2005), 126-127, se også note 118. For anvendte forståelse af $\delta$ ỏ $\xi \alpha$ se Silva (2014), 1: 765, NT2(c).

20. Frederick W. Danker, Walter Bauer, William Arndt, m.fl., A Greek-English lexicon of the New Testament and other early Christian literature (Chicago: University of Chicago Press $\left.{ }^{3} 2000\right)$, غ̇ंovpóvios, 1; Henry George Liddell m.fl., A Greek-English Lexicon, Rev. and augm. throughout (Oxford: New York: Clarendon Press; Oxford

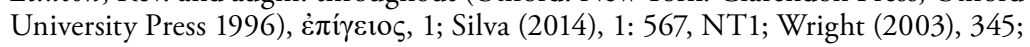
Thiselton (2000), 1268)

21. Se note 16 . 
trast, der vægtlægger forskelligheden af deres $\delta$ ó $\xi \alpha ;$ “...”på den ene

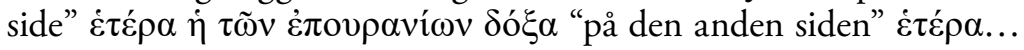

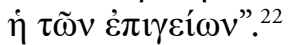

3. Hvis det var et hierarki, som lå til grund for opremsningen, er det i hvert fald tydeligt ud fra Gen 1,26-28, at det er mennesket og ikke himmellegemerne, som har højest rang i skaberværket, fordi det er skabt i Guds billede. ${ }^{23}$

15,39-41 eksemplificerer, at Gud er i stand til at skabe mange forskellige slags $\sigma \omega ́ \mu \alpha \tau \alpha$ med stor diversitet i $\delta$ ò $\xi \alpha$, og derfor kan han også give de døde en legemlig opstandelse, ligesom han giver ethvert frø dets eget legeme (15,36-38) (Thiselton 2000, 1270; Fee 2014, 865-866; Fitzmyer 2008, 586).

\section{5,42-44a legemet for og efter opstandelsen}

I 15,42-44 appliceres så-metaforen på opstandelsen gennem fire antitetiske kontraster mellem legemets nuværende tilstand og dets opstandelsestilstand. Dette ses ved brugen af verberne $\sigma \pi \varepsilon i ́ \rho \varepsilon \tau \alpha$ r

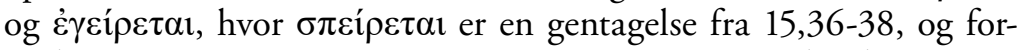

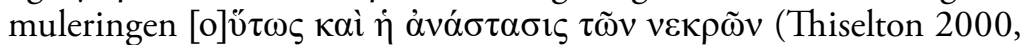
1271; Wright 2003, 347; Ware 2014, 821-822. Delvist Fee 2014, 867; Asher 2000, 106). Det diskuteres, hvad der er subjekt for de to verber i 15,42-44a. Nogle mener, det er et upersonligt implicit subjekt, hvor verberne forstås passivt (Barrett 1968, 372). Andre mener, der er to forskellige subjekter $(\sigma \omega ́ \mu \alpha \tau \alpha)$ - et for hvert af verberne. ${ }^{24}$ Disse forslag bør afvises, da det i konteksten og ud fra græsk grammatik er bedst at bestemme "legemet" som subjektet for begge verber i alle antiteserne (Ware 2014, 821-822). Dette er tilfældet, fordi så-metaforen aktualiseres i antiteserne, og da det er det nøgne frø, der er en analogi for legemet, giver det mening, at legemet også er subjekt i aktualiseringen. Hertil er fokus i konteksten netop legemet, og hvad der sker med det i opstandelsen (ibid., 822-823). Derudover er غ̇v $\varphi \theta 0 \rho \tilde{\alpha}$ adjektivisk og modificerer legemet, der sås, og derfor synes det

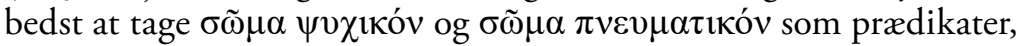
der beskriver subjektet, der sås og opstår. Dette indikerer, at subjektet

22. BDAG (2000), $\mu \varepsilon ́ v, 1 \gamma c ;$ LSJ (1996), $\mu \varepsilon v$, II.2). Friedrich Wilhelm Blass, Albert Debrunner \& Robert W. Funk, A Greek Grammar of the New Testament and Other Early Christian Literature (Chicago; London: Univ. of Chigago Press 1961), $\$ 447(1)-(2)$, siger desuden at $\mu \grave{\varepsilon} v \ldots \delta \dot{\varepsilon}$ udtrykker en markant svagere kontrast end $\mu \grave{\varepsilon} v . . . \dot{\alpha} \lambda \lambda \dot{\alpha}$, hvilket er tilfældet her, da det kun er forskellighed, der betones.

23. Wright (2003), 341; K. A. Mathews, Genesis 1-11:26, The New American Commentary 1A (Nashville, Tenn: Broadman \& Holman Publishers 1996), 160164.

24. Martin (1995), 126-131; Dunn (2002), 10-18; Sandbeck \& Nielsen (2016), 98-105; Carrier (2005), 105-139) 
er det samme legeme. ${ }^{25}$ Desuden er der et tydeligt mønster i græsk syntaks, først at et implicit subjekt kan findes eksplicit i umiddelbar kontekst, selv for verber, som beskrives som upersonlige; dernæst at et subjekt er det samme for en kæde af på hinanden følgende verber, med mindre det udtrykkes i konteksten. ${ }^{26}$ "Distinct subjects for the verbs in

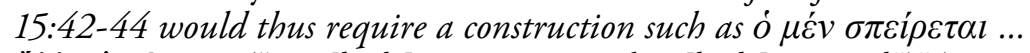

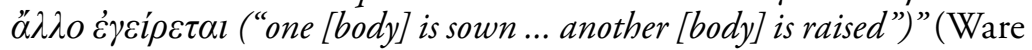
2014, 823). Fx kunne en undtagelse være et verbums objekt, der ved efterfølgende verbum anvendes som subjekt, dette gælder også for et pronomen eller nomen (ibid., 823-824); eller at person og/eller tal ændrer sig for et af verberne i kæden (Robertson 1919, 392). Intet af dette kan siges om 15,42-44, hvor subjektet skulle skifte 7 gange uden varsel, hvilket grammatisk set synes usandsynligt (Ware 2014,

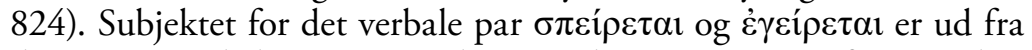
det ovenstående legemet, som lever og dør $(\sigma \pi \varepsilon i ́ p \varepsilon \tau \alpha l)$ i forgængelighed, vanære, svaghed og som et sjæleligt legeme, og det selv samme

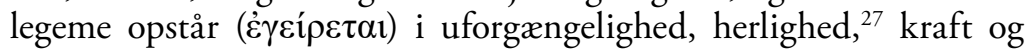
som et åndeligt legeme (Ware 2014, 824).

Dette er en kraftig indikator på en materiel kontinuitet mellem legemet før og efter opstandelsen, ligesom der er organisk forbindelse mellem frøet og planten (jf. argumentet ovenfor) (ibid., 821824; Fee 2014, 867-868). Dette problematiserer argumentet om den stoiske scala naturae eller lokative polaritet i et kosmologisk hierarki i 15,39-41, der skulle appliceres i 15,42-44a og vise, hvor legemet er placeret/bor henholdsvis nu og i opstandelsen. ${ }^{28}$ Da 15,39-41 ikke er en lokativ polaritet $\mathrm{i}$ et kosmisk hierarki, men en henvisning til

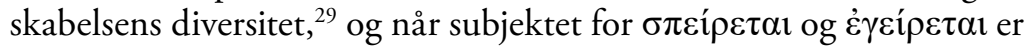
det samme, er fokus snarere temporale antiteser (Contra Asher 2000, 110-116). $\Sigma \pi \varepsilon i ́ \rho \varepsilon \tau \alpha \iota \dot{\varepsilon} v \varphi \theta o \rho \tilde{a}$ beskriver da den tilstand, hvori legemet er i sit liv på jorden under Adams falds domæne, en tilstand, som

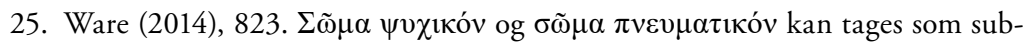
jekter for den sidste antitese(Fee 2014, 869), men det giver bedst mening, at de er prædikater, nu hvor præpositionsforbindelser "funktionelt set" fungerer sådan i de forrige antiteser.

26. Ware (2014), 822-823; Archibald Thomas Robertson, A grammar of the Greek New Testament; in the light of historical research (New York: Hodder \& Stoughton ${ }^{3}$ 1919), 391-393; Daniel B. Wallace, Greek Grammar Beyond the Basics: An Exegetical Syntax of the New Testament (Grand Rapids, MI: Zondervan 1996), 600-601, særligt note 36 .

27. Silva (2014), 1: 766, NT3(b) for oversættelsen af $\delta$ ó $\xi \alpha$

28. Asher (2000), 99-110; Jeffrey R. Asher, " $\Sigma \pi \varepsilon 1 \rho \varepsilon \tau \alpha 1:$ Anthropogenic Metaphor in 1 Corinthians 15:42-44”, JBL 120 (2001), 101-122 (104-105); Engberg-Pedersen (2010), 27-28; Martin (1995), 123-131; Dunn (2002), 10-18.

29. Se forrige sektion 
er underlagt forgængeligheden og ender med død jf. 15,21-22(-28)

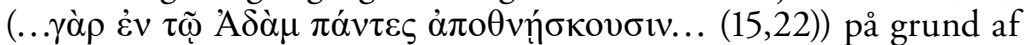
synden (jf. 15,56). Dette er grunden til, at legemet nu er i ó $\tau$ uí $\alpha$ og à $\theta \varepsilon v \varepsilon i ́ \alpha$ (Ciampa \& Rosner 2010, 811-814; Maston 2016, 541-542). Ikke sådan at forstå, at det altid var underlagt synden (se Gen 2,7; 1 Kor 15,21-22 og særligt 15,54-56). Men da legemet i høj grad er det nu, må det nyskabes. Denne nyskabelse er måde, hvorpå legemet op-

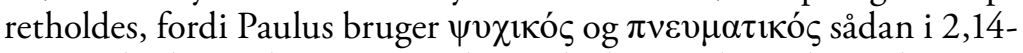
16 , og da det er det eneste andet sted i brevet, hvor denne kontrast findes, synes dens betydning relevant (Ciampa \& Rosner 2010, 817).

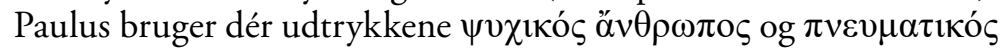
[å $v \theta \rho \omega \pi \circ \varsigma]$ som udtryk for en distinktion mellem den ikke-kristne (mennesket uden Ånden) og den kristne (mennesket med Ånden), hvori Ånden gør sin frelsende gerning, det menneske, som Ånden har

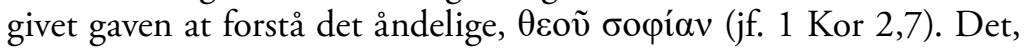

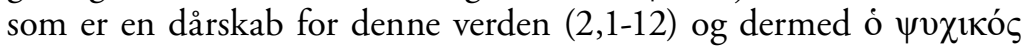

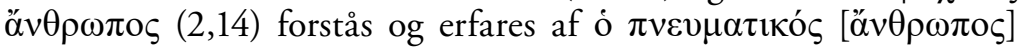
$(2,15)$, fordi det har fået indsigt i Herrens sind (jf. 2,16), og derfor kan ó $\pi v \varepsilon v \mu \alpha \tau$ «ós [óv $\theta \rho \omega \pi \circ \varsigma$ ] bedømme både den åndelige og sjælelige

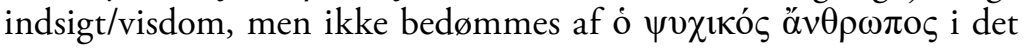
åndelige, fordi det ikke forstår det. ${ }^{30}$

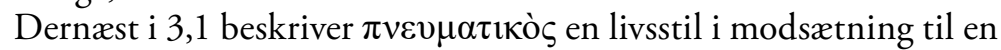
anden ( $\sigma \alpha ́ \rho \kappa ı v o ı \varsigma)$. Endvidere synes $\pi v \varepsilon v \mu \alpha \tau \iota \kappa o ́ \varsigma$ ikke anvendt om nogets materie i resten af brevet, men snarere om en virkning af/på noget enten "etisk eller funktionelt", der i større eller mindre grad har relation til Guds ånd. ${ }^{31}$ Dermed synes den bedste forståelse af $\sigma \tilde{\omega} \mu \alpha$ $\psi v \chi$ ıкóv og $\sigma \tilde{\omega} \mu \alpha \pi v \varepsilon v \mu \alpha \tau$ เóv i 15,44, at være funktionel, altså et legeme opretholdt af sjælen ( $\sigma \tilde{\omega} \mu \alpha \psi v \mathcal{\chi}$ «óv) nu og et legeme opret-

30. D. A Carson, The Cross \& Christian Ministry: An Exposition of Passages from 1 Corinthians (Grand Rapids, Michigan/Leicester: Baker Books/Inter-Varsity Press 1993), 42-61; Wright (2003), 281-283; Fee (2014), 124-129; Ware (2014), 833; David E. Garland, 1 Corinthians, Baker Exegetical Commentary on the New Testament (Grand Rapids, Michigan: Baker Academic 2003), 100-102, også Engberg-

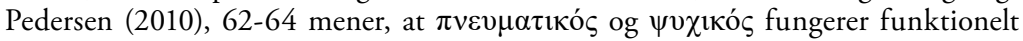
her, dog læser han 2,10-16 på baggrund af sin eksegese af 15,44 for at få sin materielle åndsforståelse til at gå op. Men det synes problematisk for hans tolkning at benytte en stærkt omdiskuteret tolkning af $\pi v \varepsilon v \mu \alpha \tau t \kappa o ́ \varsigma$ i 15,44 til at forstå 2,14-16. Ville en omvendt læsning ikke være mere naturlig? Se også diskussionen af Engberg-Pedersens åndsforståelse hos N.T. Wright, Paul and the Faithfulness of God: Book 2: Parts III and IV, Christian Origins and the Question of God 4 (Minneapolis: Fortress Press 2013), 1383-1407.

31. Silva (2014), 3: 818-820, NT7(g); Maston (2016), 547; Wright (2003), 282-84; 347-52). Betydning af -1кo endelsen er normalt etisk/funktionel. cf. Witherington III (1995), 308-309; Wright (2013), 1401; Ware (2014), 833-834. Der forefindes undtagelser (Carrier 2005, 128-129), dog synes 15,44 ikke at være en. 
holdt og styret af Ånden ( $\sigma \tilde{\omega} \mu \alpha \pi v \varepsilon v \mu \alpha \tau$ เóv) i opstandelsen. ${ }^{32}$ Mao. en tilstandsændring og ikke en materieændring.

\section{5,44b-49: Den forste og sidste Adam}

I 15,44b-49 fortsættes og uddybes argumentet om, hvorledes legemets opstandelsestilstand adskiller sig fra den nuværende tilstand. Det sker

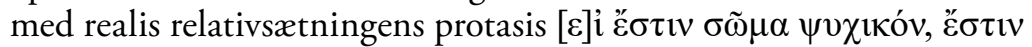

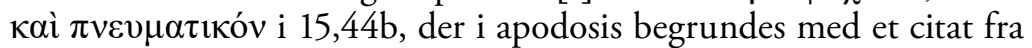
Gen 2,7 om Adams skabelse, som stilles overfor Kristus, den sidste Adam. ${ }^{33}$ Tekstens baggrund i Genesis er åbenlys pga. citatet fra Gen 2,7, men forholdet mellem den første og sidste Adam er omdiskuteret både angående, hvor Paulus finder sit belæg for at opstille den første og sidste Adam, hvad antitesen betyder, og hvordan den anvendes i konteksten. På den ene side har man argumenteret for en GT-baggrund og på den anden side for en græsk/jødisk filosofisk baggrund repræsenteret af Filons teori om de to mennesker. ${ }^{34}$

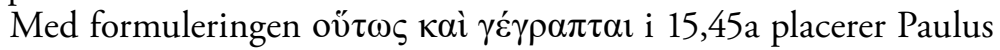
baggrunden for de to Adam'er i GT og ikke hos en antik jødisk fortolker af GT, fordi Paulus altid henviser til helligskrift med denne formulering. Dertil er Filons teori ikke kongenial med Paulus' argument, selvom de bruger noget af det samme vokabular, grundet legemernes kronologi i 15,46 og det eskatologiske og soteriologiske spørgsmål, der ligger til grund for argumentet i 1 Kor $15 .{ }^{35}$ Hertil udfordres teorien af, at $\pi v \varepsilon v \mu \alpha \tau$ ikó $\varsigma$ betegner legemets opretholdelse. ${ }^{36}$ Det synes derfor mere naturligt at forstå de to Adam'er ud fra Genesis, som eksplicit ligger til grund for kapitlets argumentation (Contra Engberg-Pedersen 2010, 29; Nordgaard 2011).

Allusionerne til Genesis i 1 Kor 15 er allerede tydelige i 15,20-28, hvor årsagen til menneskets død kædes sammen med Adam (15,2122), allusionerne forsættes i kapitlet, særligt i 15,36-41, som vist ovenfor, og selvfølgelig i Gen 2,7-citatet (Maston 2016, 541-542). Nu hvor skabelsesberetningen i Genesis har betydning for argumentet i 1 Kor 15, bør dødens forhold til Adams synd i 1 Kor 15 belyses. Adam

32. Fee (2014), 869-870; Thiselton (2000), 1275-1281; Barrett (1968), 372-373; Raymond F. Collins, First Corinthians, Sacra pagina series 7 (Collegeville, Minnesota: Liturgical Press 1999), 567. Contra Engberg-Pedersen (2010), 27-28.

33. Asher (2000), 114, men kun i forhold til grammatikken.

34. Delvist Benjamin L. Gladd, "The Last Adam as the 'Life-Giving Spirit' Revisited: A Possible Old Testament Background of One of Paul's Most Perplexing Phrases", WTJ 71 (2009), 297-309 (297-298).

35. Maston (2016), 533-534, 841-842; Fee (2014), 875. Contra Stefan Nordgaard, "Paul's Appropriation of Philo's Theory of 'Two Men' in 1 Corinthians 15.45-49", NTS 57 (2011), 348-365; Engberg-Pedersen (2010), 29.

36. Forrige sektion; Maston (2016), 541-548. 
beskrives som dødens årsag i 15,21-22. Synden beskrives i 15,3; 17; 56: Jesus døde for vores synd $(15,3)$, hvis Jesus ikke opstod, gælder synden stadig $(15,17)$, og synden er dødens brod $(15,56)$. Disse kædes ikke eksplicit sammen her, som i Rom 5, da Paulus fokuserer på døden som det problem, opstandelsen løser (ibid., 542). Dog ligger det implicit i teksten, fordi det er eksplicit i Genesis 1-3, som fylder meget i argumentet. Adams død kom nemlig ind i verden ved forbandelsen i Gen 3,19 pga. synden, og det må være det, Paulus har i tanke i 1 Kor 15,21-22 og 56 (Ciampa \& Rosner 2010, 762-764; Fee 2014,

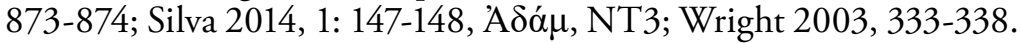
Contra Barrett 1968, 374; Maston 2016, 542).

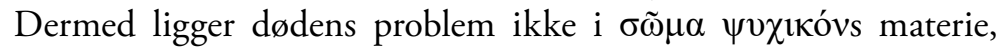

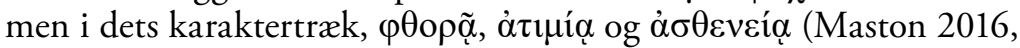
542-543. Contra Engberg-Pedersen 2010; Martin 1995; Asher 2000, 2001; Dunn 2002; Nordgaard 2011; Carrier 2005; Sumney 2009; Schmisek 2015) grundet Adams fald (jf. 15,21-22; 56), og løsningen er hovedfokusset i 15,35-58. Derfor er citatet fra Gen 2,7 ikke prooftexting, men en velovervejet prioritering for at beskytte argumentet mod misforståelser og lede læserne til en bedre forståelse af problemet og dets løsning. Dette gør Paulus ved gentagende at alludere til Genesis, og derigennem forberedes læseren på Gen 2,7-citatet (Maston 2016, 543; Ciampa \& Rosner 2010, 818-819). Antiteserne i 15,42-44 kan ses som en udlægning af citatet på forhånd, idet den første Adam identificeres med legemets nuværende tilstand og den sidste Adam med legemets opstandelsestilstand, således at antiteserne forklarer forskellene mellem den første Adam (forgængelig, skadet af faldet) og den sidste Adam (forherliget og uforgængelig). Dermed bliver skriftcitatet og kontrasten mellem den første og sidste Adam argumentets klimaks, som understreger nødvendigheden af en eskatologisk nyskabelse af legemet. Løsningen på den første Adams problem, døden, er den opstandne Kristus, dvs. den sidste Adam, den livgivende ånd (Maston 2016, 543-544). Dette bunder i en nøje læsning af Genesis 2,7 i eskatologisk lys fra Ez 37,1-14, der er stærkt forbundet med Gen 2,7, fordi Ez 37-teksten taler om nyskabelse og en opstandelse af Isralitterne ved Guds Ånd som den aktive livgiver. ${ }^{37}$ Den første Adam er

37. Maston (2016), 545-546; Mathews (1996), 196. Delvist Ciampa \& Rosner

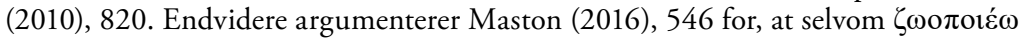
ikke er eksplicit i Ez 37, anvender Paulus ordet i en kontekst, som også er influeret af Ez 37 i 2 Kor 3,6, og derfor er det sandsynligt, dette også er tilfældet i 1 Kor 15; men uanset dette er det klart ud fra Ez 37, at Guds ånd er den, der gør levende. Contra Gladd (2009), som mener, den sidste Adam har baggrund i Gen 5,3, fordi det alluderes i 15,49 , hvilket giver mening dér, men $\pi v \varepsilon v \tilde{\mu} \mu \alpha \zeta_{\omega} \pi$ oเoṽv forklares ikke af, at de troende skal bære Kristi billede. Derfor forklarer Ez 37,1-14 bedre teksten end Gen 5,3. 


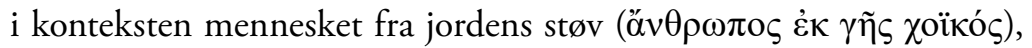
der efter sit fald (implicit i kapitlet) bærer karaktertrækkene $\varphi \theta 0 \rho \tilde{\alpha}$,

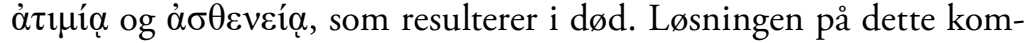
mer i kraft af Kristus, ó દ̌ $\sigma \chi \alpha \tau o \zeta$ 'A $\delta \grave{\alpha} \mu$, som i kraft af sin opstandelse

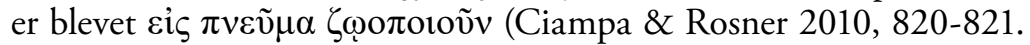
Delvist Maston 2016, 545-546). Dermed er den sidste Adam den antitetiske modsætning til den første Adam, fordi hans tilstand og karaktertræk er modsat den første (ibid., 545-546). Kun den, som bærer den sidste Adams billede, får sandt liv og opstandelse og arver Guds rige (Garland 2003, 734-735; Ciampa \& Rosner 2010, 820; Fee 2014,

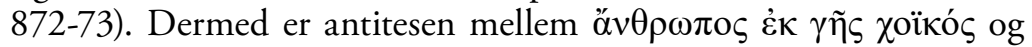

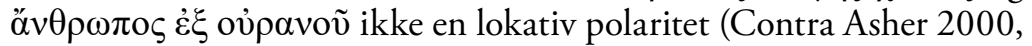
111-116; Engberg-Pedersen 2010, 28-30), da den går på karaktertræk, soteriologi og eskatologi (Witherington III 1995, 309). öv $\theta \rho \omega \pi \mathrm{o} \varsigma \dot{\varepsilon} \kappa$

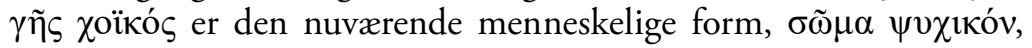
som kommer før $\sigma \tilde{\omega} \mu \alpha \pi v \varepsilon v \mu \alpha \tau \imath \kappa o ́ v$ (jf. 15,46). Denne krop er underlagt dødeligheden i sit støv uden adgang til Guds eskatologiske

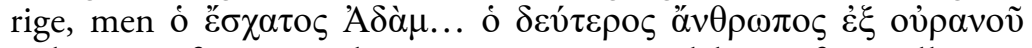
er kommet for at give liv og gennem opstandelse og forvandling at føre støvkroppen ind i den nye skabelse til en forbedret kødelig eksistens med udødelige karaktertræk (Witherington III 1995, 309-310; Maston 2016, 546-547. Delvist Ciampa \& Rosner 2010, 820-822; Fee 2014, 876-878. Contra Asher 2000, 110-117; Carrier 2005, 132135; Engberg-Pedersen 2010, 30-31; Garland 2003, 736-737). I 15,48 gøres det også eksplicit, at den første Adam er jordisk med tilhørende karaktertræk, og at alle jordiske mennesker er formet efter ham; dette gør sig ligeledes gældende for den sidste Adam: Han er himmelsk, og det skal de troende også blive (Fee 2014, 878).

\section{5,50-54a Forvandling og ikladning}

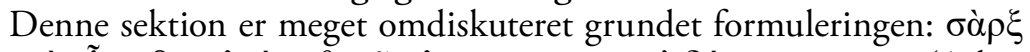

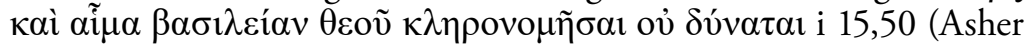
2000, 146-147). Før betydningen af dette udsagn kan fastlægges, må

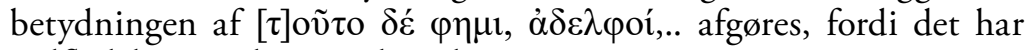
indflydelse på udsagnets betydning.

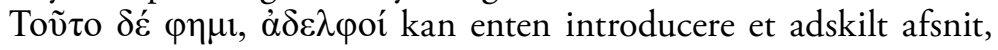
som dog fungerer som konklusion på 15,35-49 (Collins 1999, 573574; Thiselton 2000, 1290-1291; Barrett 1968, 379), eller tilføje nye elementer til argumentet i det efterfølgende, mens det stadig er en forsættelse af det forrige (Fee 2014, 883-884), eller opsummere, hvad der er sagt indtil nu, inden et emfaseskift (Engberg-Pedersen 2010, 31, se også note 83; Asher 2000, 151-152; Dunn 2002, 12-13). 
Selvom $\delta \varepsilon ́$ tages adversativt, synes det svært at forstå 15,50-54a adskilt som konklusion på argumentet (Fee 2014, 882-883), da fokus skifter fra død og opstandelse til opstandelse og forvandling (Ware $2014,818-819)$. Dermed introducerer $\delta \varepsilon \dot{e}$ et emfaseskift. Selvom det efterfølgende på sin vis opsummerer argumentet i det forrige $(15,35$ 49), synes det bedst at oversætte "men dette jeg siger, brødre...", fordi

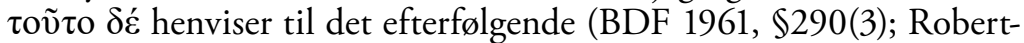
son 1919, 698; Fee 2014, 882-83; Wright 2003, 356-357; Ciampa \&

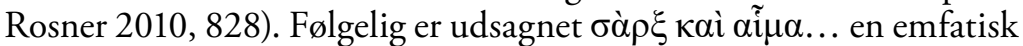
parallelisme, der erklærer hvem der arver Guds rige (Wright 2003, 356-357; Ciampa \& Rosner 2010, 828; Fee 2014, 882-883).

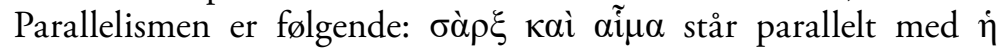

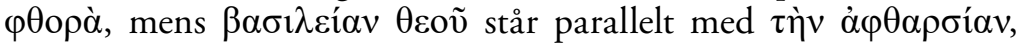
som vist herunder:

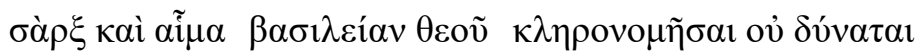

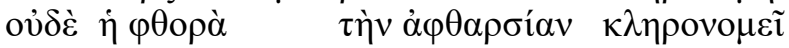

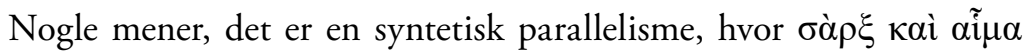
er de levende og $\dot{\eta} \varphi \theta$ opò lig i forrådnelse (Barrett 1968, 379; Thiselton 2000, 1291). Det synes ikke at være tilfældet, da $\varphi \theta$ opò er et hellenistisk udtryk med samme betydning som det hebraiske udtryk

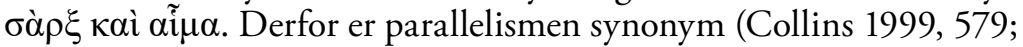
Garland 2003, 740-741; Ciampa \& Rosner 2010, 828 note 321; Fee 2014, 883, se også note 369; Wright 2003, 359; Asher 2000, 154-55; Fitzmyer 2008, 603).

Parallelismen betyder, at kød og blod ikke arver Guds rige, fordi

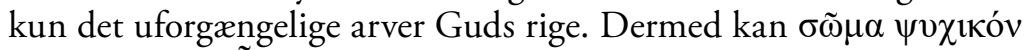

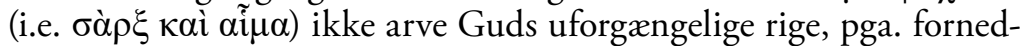
relsen i støvkroppens forgængelighed $(15,42-49)$ ved Adams fald, hvor legemet blev bundet under syndens og dødens magt (jf. 15,2122; 56) (Ciampa \& Rosner 2010, 827-28; Wright 2003, 359; Thiselton 2000, 1291). Paulus bruger $\sigma \alpha ̀ \rho \xi \kappa \alpha i ̀ ~ \alpha \tilde{\mu} \mu \alpha$ i Gal 1,16 på en lignede måde, hvor han beskriver menneskeheden med vægtlægning på dets svaghed og forgængelighed. ${ }^{38}$ Konteksten bakker også op om, at der er tale om legemet i dets forgængelige tilstand. ${ }^{39}$ Derfor må det forvandles, så støvkroppens karaktertræk bliver udskiftet med himmelske karaktertræk (ikke materien) (Ware 2014, 825-831).

Hemmeligheden ( $\mu v \sigma \tau \eta ́ \rho t o v)$ er forvandlingen, som er det centrale i denne sektion af argumentet. Det vigtigste verbum er $\alpha \lambda \lambda \alpha \gamma \eta \sigma o ́ \mu \varepsilon \theta \alpha$.

38. Silva (2014), 4: 256, NT2(b). Cf. Thiselton (2000), 1291. LXX bruger begrebet om menneskelig svaghed og forgængelighed.

39. Se forrige sektion. 
Nogle mener, at forvandlingen kun omhandler de levende, der lever ved Jesu genkomst (Wright 2003, 357). Men pga. det adversative $\delta \grave{\varepsilon}$ er det mere nærliggende at forstå $\pi \alpha ́ v \tau \varepsilon \varsigma \delta \grave{\varepsilon} \alpha \dot{\alpha} \lambda \lambda \alpha \gamma \eta \sigma o ́ \mu \varepsilon \theta \alpha$ refere-

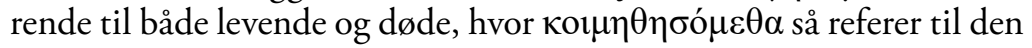
del af $\pi \alpha ́ v \tau \varepsilon \varsigma$, der lever ved genkomsten. Dermed skal både levende og døde forvandles, før de kan arve Guds rige, og det sker enten gennem død og opstandelse eller på et øjeblik for dem, som lever ved genkomsten. Gentagelsen af $\alpha \lambda \lambda \alpha \alpha \gamma \eta \sigma o ́ \mu \varepsilon \theta \alpha$ i 15,52 understreger dets vigtighed (Beale \& Gladd 2014, 130-131; Ware 2014, 825; Fee 2014, 884-887). Men før fortolkning af $\alpha \lambda \lambda \alpha \gamma \eta \sigma o ́ \mu \varepsilon \theta \alpha$ gennemføres, bør subjekterne i 15,53-54a betragtes.

Subjekterne for infinitivkonstruktionerne i 15,53 og konjunktiver-

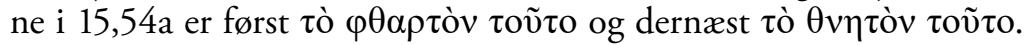
Det vigtige er så, hvad pronomenet $\tau$ oṽ $\tau$ o referer til. Det mest nærliggende er legemet i dets forgængelige tilstand, fordi $\varphi \theta \alpha \rho \tau o ̀ v ~ o g$

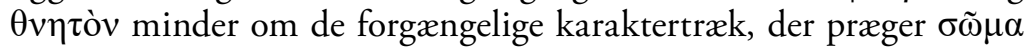

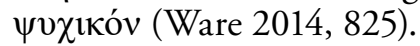

Dette betyder, at legemet i dets fordærvelige tilstand iklædes ( $\dot{\varepsilon} \nu \delta v ́ \sigma \alpha \sigma \theta \alpha \imath)$ ufordærvelighed, og det selvsamme dødelige legeme

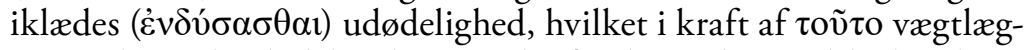
ger, at det er det dødelige legeme, der får de nye himmelske karaktertræk, der kan arve Guds rige (Ware 2014, 825; Beale \& Gladd 2014, 132-134).

Dette leder til betydningen af $\dot{\alpha} \lambda \lambda \alpha \gamma \eta \sigma o ́ \mu \varepsilon \theta \alpha$. Nogle mener, at forvandlingen er en materieforandring, fordi Paulus skulle anvende aristotelisk filosofi i form af "substantiv forandring". Dette betyder, at den kødelige krop forbliver selvidentisk den samme, men hele dens materie ændres fuldstændigt til en krop af pneumatisk stof. ${ }^{40}$ Dette synes ikke at være tilfældet af tre grunde:

1: Konteksten i kapitlet har vist, at Paulus' sprogbrug og argument ikke beror på en materieforandring, men på en forandring af karaktertræk og måden, legemet opretholdelse på, altså dets kvalitet.

2: Selv hvis Paulus anvender filosofisk sprog ved brugen af $\dot{\alpha} \lambda \lambda \alpha \dot{\sigma} \sigma \sigma \omega$, er det mere nærliggende at forstå sprogbrugen som aristotelisk "kvalitativ forandring" frem for "substantiv forandring". Dette skyldes, at brugen af $\dot{\alpha} \lambda \lambda \alpha \dot{\sigma} \sigma \sigma \omega$ harmonerer mere med aristotelisk "kvalitativ forandring", eftersom Aristoteles i den forbindelse anvender $\dot{\alpha} \lambda \lambda$ oí $\omega \sigma \iota \varsigma$, hvis verbalform er $\dot{\alpha} \lambda \lambda$ oló $\omega$, der betydningsmæssigt er nært beslægtet med $\dot{\alpha} \lambda \lambda \alpha ́ \sigma \sigma \omega$. Dette styrkes kun af, at "substantiv forandring" hos

40. Engberg-Pedersen (2010), 32; Asher (2000), 156-166; med modifikationer Martin (1995), 128-129. Carrier (2005), 134-139 mener, $\dot{\alpha} \lambda \lambda \dot{\alpha} \sigma \sigma \omega$ betyder "at udskifte" her, men det er ikke muligt, da Paulus jf. eksegesen ovenfor ikke operer med to legemer. 
Aristoteles beskrives med begreberne $\gamma \varepsilon ́ v \varepsilon \sigma ı \varsigma$ "at få eksistens/generation" og $\varphi \theta 0 \rho \alpha ́$ i betydningen "at blive ødelagt", og selvom $\varphi \theta 0 \rho \alpha ́$ bruges i kapitlet, er det med en anden betydning (Ware 2014, 827831).

3: En del af baggrunden for argumentationen i 15,53-54 synes at være

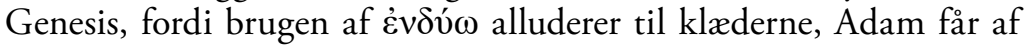

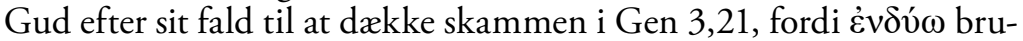
ges dér i LXX (Beale \& Gladd 2014, 132-135).

Derfor synes det bedst at forstå forvandlingen og iklædningen som en kvalitativ forandring af legemet. Således at legemets tilstand forvandles fra forgængelighed til en uforgængelighed, men materien forbliver den samme. Selvom materien forbliver kød, er det ikke at gå tilbage til før syndefaldet, men til en nyskabelsestilstand mere forherliget og ophøjet end den oprindelige, fordi Kristus er livgiveren. ${ }^{41}$

\section{5,54b-58 Døden er besejret}

I denne sektion erklærer Paulus døden for endeligt besejret og overvundet, når Jesu genkomst og opstandelsen har fundet sted. Dette skyldes, at dødens brod - synden, som er årsagen til, at mennesket er forgængeligt og dør - da vil være væk. Det er klart fra teksten, at Jesus er årsagen til, at synden og døden er besejret (15,56-57) (Delvist Ciampa \& Rosner 2010, 833-839).

Men hvad vil det sige, at døden er overvundet? Illustrationen på næste side viser:

1: Filons teori: Menneskets skabelsestilstand er åndelig (EngbergPedersen 2010, 22-26), men mennesket er i den nuværende tilstand kødelige og forgængelige. Frelsen er at vende tilbage til den oprindelige åndelige tilstand.

2: Åndsforståelsen: Skabelsestilstanden og den nuværende tilstand er kødelige - se illustrationen. Denne tilstand er i sig selv forgængelig og dødelig. Derfor er frelsestilstanden åndelig, fordi denne tilstand er udødelig.

41. Beale \& Gladd (2014), 134-135; 144-146. Beale \& Gladd nævner på s. 144-146 med henvisning til apokalyptiske tekster som bl.a. 1 Enoks bog, 2 Baruk (2. århundrede e.Kr.), at man i apokalyptisk jødedom havde en kødelig opstandelsesforståelse. Dette problematiserer en forståelse, der hævder, at man i apokalyptisk jødedom bliver stjerner ved opstandelsen (Engberg-Pedersen 2010, 28, se også note 75). I note 75 henviser Engberg-Pedersen til Dan 12,2-3 som locus classicus for denne forståelse, men det, der står i Dan 12,2-3 (MT), er, at de skal skinne "...som hvæl-

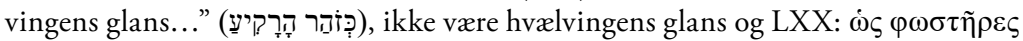

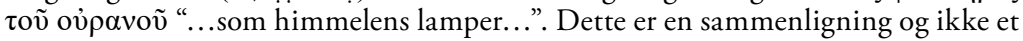
lighedstegn, se også Stephen R. Miller, Daniel, The New American Commentary 18 (Nashville, Tenn: Broadman \& Holman Publishers 1994), 316-320. 


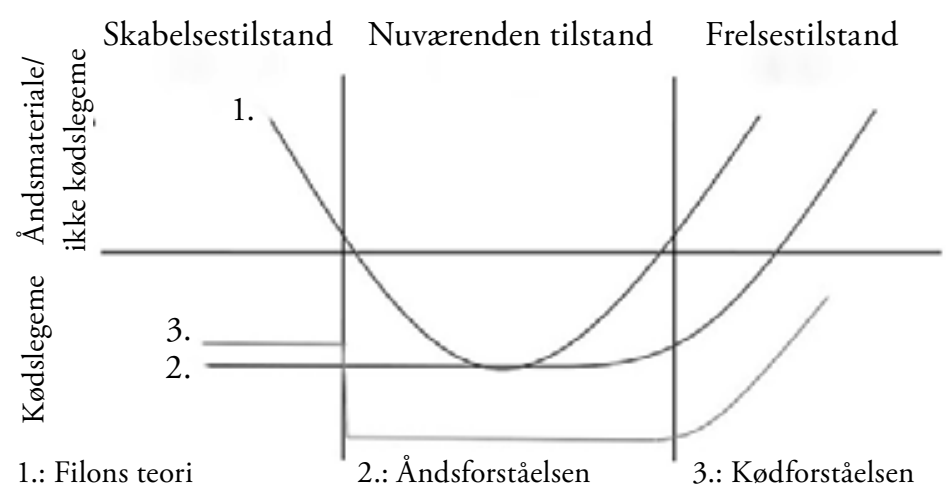

3: Kødforståelsen: Den oprindelige tilstand er kødelig uden synd, fordærvelighed og død. Den nuværende tilstand er kødelig, men den er forgængelig og dødelig på grund af Adams fald, som førte synden ind i verden (vist ved den nedadgående linje i illustrationen). Frelsestilstanden er en nyskabelse, som ikke blot fører tilbage til før faldet, men til en bedre forherliget kødelig tilstand end i begyndelsen.

Pointen med illustrationen er at stille spørgsmålet, om der reelt kan være tale om en overvindelse af døden i åndsforståelsen. Grunden er, at den oprindelige tilstand er god for Paulus jf. argumentationen ovenfor. Derfor ligger dødeligheden ikke i kødet, og dermed kan frelsen heller ikke være at slippe fri af kødet. Dette skyldes, at synden er årsagen til, at kødet dør. Derfor er løsningen på dødens problem at blive befriet fra synden og ikke fra kødet. Hvis frelsestilstanden er ånd, må den oprindelige tilstand dermed også være det, men fordi døden er noget, der er påført kødet, skal døden også besejres i kødet. Åndsforståelsen er problematisk, fordi døden ikke kan siges at være overvundet ved at legemet forvandles til pneumatisk stof. Frelsen bør være i kødet, hvis skabelsestilstanden er i kødet.

\section{Konklusion}

Den eksegetiske, sproglige gennemgang af 1 Kor 15,35-58 viser følgende om opstandelseslegemets karakter: Legemet, som opstår, er det samme legeme, som sås, men legemets tilstand er markant anderledes end før opstandelsen, også selvom dets materie forsat er kød. Det er ikke kødet, som er årsagen til menneskets forgængelighed, men den første Adams synd og fald, som har ødelagt den gode kødelige skabelsestilstand. Derfor er legemet i en tilstand af forgængelighed, svag- 
hed, vanære og dødelighed efter faldet, fordi synden præger denne

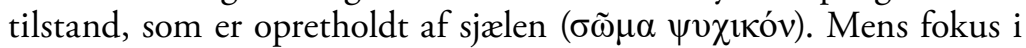
kapitlet er, hvorledes dødens problem kan løses, er årsagen til døden kun implicit. Løsningen på dødens problem er at føre legemet ind i en ny tilstand, som ikke er præget af de fornedrede karaktertræk. Den, som kan gøre det, er den sidste Adam - Kristus, som ved sin opstandelse blev en levendegørende ånd, som giver dem, der tror på ham, en nyskabelsestilstand bedre end den oprindelige skabelsestilstand. Den tilstand er nødvendig for at kunne arve Guds rige, og fordi den er

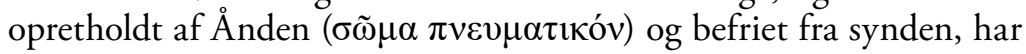
den derfor nye og bedre karaktertræk end den nuværende tilstand, nemlig uforgængelighed, herlighed, kraft og udødelighed. Overgangen til den nye tilstand sker gennem forvandling og iklædning enten gennem død og opstandelse eller på et øjeblik ved Jesu genkomst for dem, der endnu lever da. Opstandelseslegemets karakter går derfor ikke på materien, men på, hvad der holder det i live: sjælen eller Guds levende Ånd gennem den sidste Adam, Jesus Kristus. 